\title{
PEMAHAMAN MASYARAKAT TERHADAP UUPKDRT SERTA DAMPAKNYA TERHADAP TERJADINYA KEKERASAN DALAM RUMAH TANGGA
}

\author{
Oleh :
}

\author{
Ahmad Yunus \\ Email : ahmadyunus37x@gmail.com \\ Universitas Ibrahimy Situbondo \\ Supianto \\ Email:supianto@uij.ac.id \\ Universitas Islam Jember
}

\begin{abstract}
Abstrak
Rumah tangga yang harmonis bisa terjadi karena beberapa faktor yang mendukung, diantaranya adalah faktor kenyamanan, kecocokan, adanya tujuan dan kepercayaan. Sebaliknya, rumah tangga yang tidak harmonis terjadi karena adanya beberapa faktor penyebab, diantaranya tidak adanya kecocokan dan sering terjadi konflik. Penelitian ini berfokus pada bagaimanakah tingkat pemahaman dan dampak dari pemahaman masyarakat terhadap UUPKDRT. Tingkat pemahaman masyarakat Desa Cangkring, Kecamatan Jenggawah, terhadap Undang-Undang PKDRT adalah masih rendah. Mereka tidak tahu bahwa kekerasan itu banyak macamnya, antara lain kekerasan fisik, kekerasan psikologis, kekerasan seksual, kekerasan ekonomi dan kekerasan penelantaran rumah tangga. Dampak dari rendahnya pemahaman masyarakat Desa Cangkring tentang Undang-Undang PKDRT dan juga rendahnya pemahaman tentang berbagai bentuk kekerasan dalam rumah tangga menyebabkan tingginya kejadian kekerasan dalam rumah tangga baik terjadi secara disadari atau tidak.
\end{abstract}

Kata kunci : Pemahaman, Kekerasan dalam rumah tangga, dampak

\begin{abstract}
Harmonious households can occur due to several factors that support, including factors such as comfort, compatibility, the existence of goals and trust. Conversely, households that are not harmonious occur because of several factors, including the lack of compatibility and frequent conflicts. This research focuses on how the level of understanding and the impact of community understanding of UUPKDRT. The level of community understanding of Cangkring Village, Jenggawah Subdistrict, regarding the PKDRT Law is still low. They do not know that there are many kinds of violence, including physical violence, psychological violence, sexual violence, economic violence and domestic violence violence. The impact of the low understanding of the people of Cangkring Village on the PKDRT Law and also the low understanding of various forms of violence in household causes the high incidence of violence in the household whether it is realized consciously or not.
\end{abstract}

Keywords: Understanding, Domestic violence, impact 


\section{PENDAHULUAN}

\subsection{Latar Belakang}

Pernikahan merupakan sesuatu yang sakral di kalangan masyarakat dan juga bagian dari ibadah. Allah telah menciptakan segala sesuatunya untuk berpasangpasangan, ada laki-laki dan ada perempuan.

Allah memberikan karunia kepada manusia dengan adanya sebuah ikatan pernikahan antara laki-laki dan perempuan. Pernikahan ini bertujuan untuk melanjutkan keturunan atau generasi penerusnya. Menurut Undang-Undang No 1 tahun 1974 Pasal 1 tentang perkawinan dijelaskan bahwa perkawinan ialah ikatan lahir batin antara seorang pria dan seorang wanita sebagai suami istri dengan tujuan membentuk keluarga (rumah tangga) yang bahagia dan kekal berdasarkan Ketuhanan Yang Maha Esa. $^{1}$

Rumah tangga merupakan unit terkecil dalam masyarakat sebagai wadah dan proses pergaulan hidup. ${ }^{2}$ Dalam membina rumah tangga ada yang berlangsung secara harmonis dan ada juga yang mengalami sebaliknya. Rumah tangga yang harmonis bisa terjadi karena beberapa faktor yang mendukung, diantaranya adalah

\footnotetext{
${ }^{1}$ Moerti Hadiati Soeroso, Kekerasan Dalam Rumah Tangga: Dalam Perspektif Yuridis Viktimologis, (Jakarta: Sinar Grafika, 2010), hlm. 62

2 Soerjono Soekanto, Sosiologi Keluarga Tentang Ikhwal Keluarga, Remaja dan Anak, (Jakarta: Rineka Cipta, 2009), hlm. 1
}

faktor kenyamanan, kecocokan, adanya tujuan dan kepercayaan. Sebaliknya, rumah tangga yang tidak harmonis terjadi karena adanya beberapa faktor penyebab, diantaranya tidak adanya kecocokan dan sering terjadi konflik. Konflik yang terjadi dalam kehidupan berumah tangga memang tidak bisa untuk dipungkiri. Ada pasangan yang mampu dan berhasil menyelesaikan konflik itu dengan baik seperti musyawarah yang dilakukan antara kedua belah pihak. Namun sebaliknya, konflik yang berakhir dengan tidak baik akan berujung dengan tindak kekerasan didalam keluarga.

Menurut Pasal 89 Kitab UndangUndang Hukum Pidana (KUHP), kekerasan ialah membuat orang pingsan atau tidak berdaya disamakan dengan menggunakan kekerasan. $^{3}$ Tindak Kekerasan Dalam Rumah Tangga (KDRT) bukanlah sesuatu hal baru yang kita dengar. Kekerasan dalam rumah tangga tersebut sebagian besar dialami oleh istri yang dilakukan oleh suami mereka sendiri. Faktor pendorong terjadinya kekerasan dalam rumah tangga, dapat disebabkan oleh adanya berbagai faktor, dapat dipengaruhi oleh faktor dari luar/lingkungan atau faktor dari dalam diri pelaku tindak kekerasan dalam rumah tangga. ${ }^{4}$

\footnotetext{
${ }^{3}$ Moerti Hadiati Soeroso, Kekerasan Dalam Rumah Tangga: Dalam Perspektif Yuridis Viktimologis, (Jakarta: Sinar Grafika, 2010), hlm.58

${ }^{4}$ Ibid. hlm. 75
} 
Kekerasan terhadap perempuan bisa terjadi di mana saja, kapan saja dan oleh siapa saja. ${ }^{5}$ Bentuk kekerasan terhadap perempuan yang juga dapat dikategorikan sebagai kejahatan seksual atau gender based violence adalah kekerasan dalam keluarga atau yang dikenal dengan istilah domestic violence. ${ }^{6}$ Pengertian KDRT (Kekerasan Dalam Rumah Tangga) adalah setiap perbuatan terhadap seseorang terutama perempuan, yang berakibat timbulnya kesengsaraan atau penderitaan secara fisik, seksual, psikologis, dan atau penelantaran rumah tangga termasuk ancaman untuk melakukan perbuatan, pemaksaan, atau perampasan kemerdekaan secara melawan hukum dalam lingkup rumah tangga. ${ }^{7}$ Kekerasan dalam rumah tangga sendiri bisa terjadi karena berbagai hal dan alasan.

Berdasarkan studi yang dilakukan dengan menggunakan analisis gender ternyata banyak ditemukan ada manifestasi ketidakadilan seperti: pertama, terjadi marginalisasi (pemiskinan ekonomi) terhadap kaum perempuan, kedua, terjadi subordinasi terhadap salah satu jenis kelamin, umumnya kepada kaum

5 Fathul Djannah, Kekerasan Terhadap Istri, (Yogyakarta: LkiS, 2003), hlm. 2

6 Dadang S. Anshori, dkk, Membincangkan Feminisme: Refleksi Muslimah Atas Peran Sosial Kaum Wanita, (Bandung: Pustaka Hidayah, 1997), hlm. 79

${ }^{7}$ Pasal 1 ayat 1 Undang-Undang Nomor 23 Tahun 2004 Tentang Penghapusan Kekerasan Dalam Rumah Tangga, Bab I Ketentuan Umum, perempuan, ketiga, pelabelan negative (stereotipe) terhadap jenis kelamin tertentu, dan akibat dari stereotipe itu terjadi diskriminasi serta berbagai ketidakadilan lainnya, keempat, kekerasan (violence) terhadap jenis kelamin tertentu, umumnya perempuan, karena perbedaan gender, kelima, karena peran gender perempuan adalah mengelola rumah tangga, maka banyak perempuan menanggung beban kerja domestik lebih banyak dan lebih lama (burden). ${ }^{8}$ Persoalan kekerasan dalam rumah tangga menyangkut juga persoalan hak asasi manusia. Hak asasi manusia adalah hak-hak yang dimiliki manusia semata-mata karena ia manusia. ${ }^{9}$

Namun demikian, pada kenyataannya sebagian korban kekerasan dalam rumah tangga (perempuan/istri) dari suami memilih untuk diam atau memendam apa yang sebenarnya terjadi pada diri mereka dan bertahan dalam rumah tangganya. Seringkali tindak kekerasan semacam ini disebut hidden crime (kejahatan yang tersembunyi). Disebut demikian, karena baik pelaku maupun korban berusaha untuk merahasiakan perbuatan tersebut dari pandangan publik. Banyak istri yang tidak melaporkan tindak kekerasan yang

\footnotetext{
${ }^{8}$ Mansour Fakih, Analisis Gender dan Transformasi Sosial, (Yogyakarta: Pustaka Pelajar, 2012), hlm. 72-75

9 Aroma Elmina Martha, Proses Pembentukan Hukum Kekerasan Terhadap Perempuan di Indonesia dan Malaysia,(Yogyakarta: Aswaja Pressindo, 2013), hlm. 39
} 
dialaminya, bahkan cenderung menutupnutupi masalah ini, karena takut akan cemoohan dari masyarakat maupun dari keluarga sendiri. ${ }^{10}$ Budaya masyarakat ikut berperan dalam hal ini, karena tindak kekerasan apapun bentuknya yang terjadi dalam sebuah rumah tangga adalah merupakan masalah keluarga, di mana orang luar tidak boleh mengetahuinya. Apalagi anggapan bahwa hal tersebut merupakan aib keluarga dan harus ditutupi. $^{11}$

Berdasarkan uraian tersebut diatas, maka isu yang muncul yaitu apakah masyarakat mengatahui dan memahami adanya Undang-Undang Nomor 23 Tahun 2004 tentang penghapusan kekerasan dalam rumah tangga yang mengatur secara khusus tentang tindakan kekerasan dalam rumah tangga serta dampaknya terhadap terjadinya kekerasan dalam rumah tangga.

Desa Cangkring adalah salah satu desa dari 8 desa di kecamatan Jenggawah Kabupaten Jember. Berdasarkan Data Badan Pusat Statistik (BPS) Kabupaten Jember Tahun 2017, jumlah penduduk Desa Cangkring Adalah 9264 orang, yang terdiri dari 4.759 laki-laki dan 4.865 Perempuan. Dari jumlah tersebut yang telah melangsungkan perkawinan adalah 6.878

\footnotetext{
10 Moerti Hadiati Soeroso, Kekerasan Dalam Rumah Tangga Perspektif YuridisViktimologis, (Jakarta: Sinar Grafika, 2010), hlm. 1-2

${ }^{11}$ Ibid. hlm. 61-62
}

orang. Adapun penduduk yang belum bersekolah sejumlah 1.765 orang, yang masih bersekolah sejumlah 2.185 orang, penduduk yang tidak lulus SD sejumlah 1.264 orang, lulus SD sejumlah 1.387 orang, lulus SMP sejumlah 1.315, lulus SMA sejumlah 1.443 orang.

Desa Cangkring merupakan desa yang mayoritas penduduknya beragama Islam. Hal ini tercermin dari banyaknya masjid dan lembaga-lembaga pendidikan Islam. Berdasarkan data Badan Pusat Statistik Kabupaten Jember, penduduk yang beragama Islam berjumlah 9234 orang, beragama Kristen 44 Orang, beragama Katolik 7 Orang, beragama Hindu 5 orang. Adapun rumah peribadatan yang ada di Desa Cangkring yaitu 19 Masjid. Berdasarkan data Badan Pusat Statistik (BPS) Kabupaten Jember, mayoritas masyarakat Desa Cangkring bermata pencaharian sebagai petani. Lahan pertanian yang berupa persawahan dimanfaatkan untuk menanam padi, jagung, kedelai, cabai, sayuran dan buah-buahan.

\subsection{Rumusan Masalah}

1. Bagaimanakah tingkat pemahaman masyarakat terhadap Undang-Undang Nomor 23 Tahun 2004 tentang penghapusan kekerasan dalam rumah tangga?

2. Bagaimana dampak dari pemahaman masyarakat tentang Undang-Undang 
Nomor 23 Tahun 2004 Tentang penghapusan kekerasan dalam rumah tangga terhadap terjadinya kekerasan dalam rumah tangga?

\section{HASIL PENELITIAN DAN PEMBAHASAN}

\subsection{Pemahaman Masyarakat Terhadap} Undang-Undang Nomor 23 Tahun 2004 Tentang Penghapusan

\section{Kekerasan Dalam Rumah Tangga}

Kekerasan (Terhadap Perempuan) dalam Rumah Tangga, secara ringkas adalah setiap tindakan kekerasan verbal maupun fisik, pemaksaan atau ancaman pada nyawa yang dirasakan pada seorang perempuan, apakah masih anak-anak atau sudah dewasa, yang menyebabkan kerugian fisik atau psikologis, penghinaan atau perampasan kebebasan dan yang melanggengkan subordinasi perempuan. Adapun pengertian kekerasan dalam rumah tangga, sebagaimana tertuang dalam rumusan Pasal 1 Deklarasi Penghapusan Tindakan Kekerasan terhadap Perempuan dapat disarikan sebagai setiap tindakan berdasarkan jenis kelamin yang berakibat kesengsaraan atau penderitaan perempuan secara fisik, seksual, atau psikologis, termasuk ancaman tindakan tertentu, pemaksaan atau perampasan secara sewenang-wenang baik yang terjadi di depan umum atau dalam kehidupan pribadi (keluarga). ${ }^{12}$

Lebih tegas lagi dapat dikatakan bahwa kekerasan terhadap perempuan dalam rumah tangga terutama digunakan untuk mengontrol seksualitas perempuan dan peran reproduksi mereka. Hal ini sebagaimana biasa terjadi dalam hubungan seksual antara suami dan istri di mana suami adalah pihak yang membutuhkan dan harus dipenuhi kebutuhannya, dan hal ini tidak terjadi sebaliknya.

Lebih jauh lagi Maggi Humm menjelaskan bahwa beberapa hal di bawah ini dapat dikategorikan sebagai unsur atau indikasi kekerasan terhadap perempuan dalam rumah tangga yaitu: ${ }^{13}$

1. Setiap tindakan kekerasan baik secara verbal maupun fisik, baik berupa tindakan atau perbuatan, atau ancaman pada nyawa.

2. Tindakan tersebut diarahkan kepada korban karena ia perempuan. Di sini terlihat pengabaian dan sikap merendahkan perempuan sehingga pelaku menganggap wajar melakukan tindakan kekerasan terhadap perempuan.

\footnotetext{
12 Rahman, Anita. (2006). Pemberdayaan PerempuanDikaitkan Dengan 12 Area of Concerns (Issue Beijing, 1995). Tidak diterbitkan, Universitas Indonesia, Jakarta, Indonesia.

${ }^{13}$ WHO. (2006). Menggunakan Hak Asasi Manusia Untuk Kesehatan Maternal dan Neunatal: Alat untuk Memantapkan Hukum, Kebijakan, dan Standar Pelayanan. Jakarta: Dep. Kes. RI.
} 
3. Tindakan kekerasan itu dapat berbentuk hinaan, perampasan kebebasan, dll.

4. Tindakan kekerasan tersebut dapat merugikan fisik maupun psikologis perempuan.

5. Tindakan kekerasan tersebut terjadi dalam lingkungan keluarga atau rumah tangga.

Dalam konteks Indonesia, kondisi dari budaya yang timpang telah menyebabkan hukum, dan sistem hukum (materiil hukum, aparat hukum, budaya hukum) yang ada kurang responsif dalam melindungi kepentingan perempuan. KUHAP sangat minim membicarakan hak dan kewajiban istri sebagai korban, ia hanya diposisikan sebagai saksi pelapor atau saksi korban. Begitu pula yang tercantum dalam Undang-Undang. Nomor 1 Tahun 1974 Tentang Perkawinan Pasal 31 ayat (3): "Suami adalah kepala rumah tangga dan istri adalah ibu rumah tangga. Meski demikian, KUHP juga memuat peluang istri untuk mendapat keadilan. Kekerasan dan penganiayaan terhadap istri dalam KUHP merupakan tindak pidana yang sanksinya lebih besar sepertiga dari tindak pidana penganiayaan biasa atau dilakukan oleh dan terhadap orang lain, sebagaimana diterangkan dalam Pasal 351 s.d.355 KUHP.

Pernyataan dalam KUHP tersebut dipertegas lagi dengan keluarnya Undang-
Undang. Nomor 23 Tahun 2004 Tentang Kekerasan Dalam Rumah Tangga (KDRT) pada tanggal 22 September 2004 yang merupakan hasil kerja cukup panjang dari berbagai elemen bangsa, baik dari pemerintah, parlemen, dan tentu saja masyarakat luas yang dalam hal ini diwakili oleh lembaga-lembaga yang mempunyai perhatian serius terhadap penyelesaian kekerasan dalam rumah tangga dan pembangunan hukum yang adil bagi seluruh lapisan masyarakat.

Adapun definisi kekerasan dalam rumah tangga menurut Undang-Undang Nomor 23 Tahun 2004 yaitu: "Kekerasan dalam rumah tangga adalah setiap perbuatan terhadap seseorang terutama perempuan, yang berakibat timbulnya kesengsaraan atau penderitaan secara fisik, seksual, psikologis, dan penelantaran rumah tangga, termasuk ancaman untuk melakukan perbuatan, pemaksaan atau perampasan kemerdekaan secara melawan hukum dalam lingkup rumah tangga.

Gejala-gejala istri yang mengalami kekerasan adalah merasa rendah diri, cemas, penuh rasa takut, sedih, putus asa, terlihat lebih tua dari usianya, sering merasa sakit kepala, mengalami kesulitan tidur, mengeluh nyeri yang tidak jelas penyebabnya, kesemutan, nyeri perut, dan bersikap agresif tanpa penyebab yang jelas. Jika anda membaca gejala-gejala di atas, tentu anda akan menyadari bahwa akibat 
kekerasan yang paling fatal adalah merusak kondisi psikologis yang waktu penyembuhannya tidak pernah dapat dipastikan. ${ }^{14}$

Ratna Batara Munti menjelaskan bahwa kekerasan terhadap perempuan dalam rumah tangga dapat terjadi dalam berbagai bentuk sebagaimana diringkaskan di bawah ini yaitu $:^{15}$

1. Kekerasan fisik, langsung dalam bentuk pemukulan, pencakaran sampai pengrusakan vagina (kekerasan seksual) dan kekerasan fisik secara tidak langsung yang biasanya berupa memukul meja, membanting pintu, memecahkan piring, gelas, tempat bunga dan lain-lain, serta berlaku kasar.

2. Kekerasan psikologis, Kekerasan psikis adalah perbuatan yang mengakibatkan ketakutan, hilangnya rasa percaya diri, hilangnya kemampuan untuk bertindak, rasa tidak berdaya, dan/atau penderitaan psikis berat pada seseorang.

3. Kekerasan Seksual, Kekerasan seksual adalah setiap perbuatan yang berupa pemaksaan hubungan seksual, pemaksaan hubungan seksual dengan cara tidak wajar dan/atau tidak disukai, pemaksaan hubungan seksual dengan

14 Komnas Perempuan (2002). Peta Kekerasan Pengalaman Perempuan Indonesia.Jakarta: Ameepro.

15 Rahman, Anita. (2006). Pemberdayaan PerempuanDikaitkan Dengan 12 Area of Concerns (Issue Beijing, 1995). Tidak diterbitkan, Universitas Indonesia, Jakarta, Indonesia. orang lain untuk tujuan komersial dan/atau tujuan tertentu tidak memenuhi kebutuhan seksual istri.

4. Kekerasan Ekonomi, berupa tidak diberikannya nafkah selama perkawinan atau membatasi nafkah secara sewenang-wenang, membiarkan atau bahkan memaksa istri bekerja keras, juga tidak memberi nafkah setelah terjadi perceraian meskipun pengadilan memutuskan.

5. Penelantaran rumah tangga adalah seseorang yang menelantarkan orang dalam lingkup rumah tangganya, padahal menurut hukum yang berlaku baginya atau karena persetujuan atau perjanjian ia wajib memberikan kehidupan, perawatan, atau pemeliharaan kepada orang tersebut. Selain itu, penelantaran juga berlaku bagi setiap orang yang mengakibatkan ketergantungan ekonomi dengan cara membatasi dan/atau melarang untuk bekerja yang layak di dalam atau di luar rumah sehingga korban berada di bawah kendali orang tersebut.

Gabungan dari berbagai kekerasan sebagaimana disebutkan di atas baik fisik, psikologis, maupun ekonomis. Dari keterangan tentang berbagai macam bentuk kekerasan dalam rumah tangga tersebut dapat diketahui bahwa kekerasan tersebut adalah suatu tindakan yang out of 
control yang dapat menjadi kebiasaan jahat yang dapat merugikan pasangan. Adapun faktor-faktor terjadinya kekerasan terhadap perempuan dalam rumah tangga khususnya yang dilakukan oleh suami terhadap istri telah diungkap dalam suatu penelitian yang dilakukan oleh Diana Ribka, juga oleh Istiadah yang dapat diringkaskan sebagai berikut: ${ }^{16}$

1. Adanya hubungan kekuasaan yang tidak seimbang antara suami dan istri.

2. Ketergantungan ekonomi.

3. Kekerasan sebagai alat untuk menyelesaiakan konflik.

Jika dimuka telah diterangkan mengenai faktor pertama kekerasan dalam rumah tangga adalah ketimpangan hubungan kekuasaan antara suami dan istri. Maka di sisi lain, perimbangan antara suami dan istri, baik dalam hal pendidikan, pergaulan, penguasaan ekonomi baik yang mereka alami sejak masih kuliah, di lingkungan kerja, dan lingkungan masyarakat di mana mereka tinggal, dapat menimbulkan persaingan dan selanjutnya dapat menimbulkan terjadinya kekerasan dalam rumah tangga. Bahwa di satu sisi suami tidak mau kalah, sementara di sisi lain istri juga tidak mau terbelakang dan dikekang.

16 Sciortino, Rosalia dan Ine Smyth. (1997). Harmoni: Pengingkaran KekerasanDomestik di Jawa. Jurnal Perempuan, Edisi: 3, Mei-Juni.
Terkadang pula suami melakukan kekerasan terhadap istrinya karena merasa frustai tidak bisa melakukan sesuatu yang semestinya menjadi tanggung jawabnya. Hal ini biasa terjadi pada pasangan yang:

1. Belum siap kawin.

2. Suami belum memiliki pekerjaan dan penghasilan tetap yang mencukupi kebutuhan rumah tangga.

3. Masih serba terbatas dalam kebebasan karena masih menumpang pada orang tua atau mertua.

Dalam kasus ini biasanya suami mencari pelarian kepada mabuk-mabukan dan perbuatan negatif lain yang berujung pada pelampiasan terhadap istrinya dengan memarahinya, memukulnya, membentaknya dan tindakan lain yang semacamnya. Kesempatan yang kurang bagi perempuan dalam proses hukum. Pembicaraan tentang proses hukum dalam kasus kekerasan dalam rumah tangga tidak terlepas dari pembicaraan hak dan kewajiban suami istri. Hal ini penting karena bisa jadi laporan korban kepada aparat hukum dianggap bukan sebagai tindakan kriminal tapi hanya kesalahpahaman dalam keluarga. Hal ini juga terlihat dari minimnya KUHAP membicarakan mengenai hak dan kewajiban istri sebagai korban, karena posisi dia hanya sebagai saksi pelapor atau saksi korban. Dalam proses sidang pengadilan, sangat minim kesempatan istri 
untuk mengungkapkan kekerasan yang ia alami.

Karena kekerasan sebagaimana tersebut di atas terjadi dalam rumah tangga, maka penderitaan akibat kekerasan ini tidak hanya dialami oleh istri saja tetapi juga anak-anaknya. Adapun dampak kekerasan dalam rumah tangga yang menimpa istri adalah: ${ }^{17}$

1. Kekerasan fisik langsung atau tidak langsung dapat mengakibatkan istri menderita rasa sakit fisik dikarenakan luka sebagai akibat tindakan kekerasan tersebut.

2. Kekerasan seksual dapat mengakibatkan turun atau bahkan hilangnya gairah seks, karena istri menjadi ketakutan dan tidak bisa merespon secara normal ajakan berhubungan seks.

3. Kekerasan psikologis dapat berdampak istri merasa tertekan, shock, trauma, rasa takut, marah, emosi tinggi dan meledak-ledak, kuper, serta depresi yang mendalam.

4. Kekerasan ekonomi mengakibatkan terbatasinya pemenuhan kebutuhan sehari-hari yang diperlukan istri dan anak-anaknya.

Sebagaimana telah disebutkan di atas, bahwa kekerasan tersebut juga dapat

\footnotetext{
${ }^{17}$ WHO. (2006). Menggunakan Hak Asasi Manusia Untuk Kesehatan Maternal dan Neunatal: Alat untuk Memantapkan Hukum, Kebijakan, dan Standar Pelayanan. Jakarta: Dep. Kes. RI.
}

berdampak pada anak-anak. Adapun dampak-dampak itu dapat berupa efek yang secara langsung dirasakan oleh anak, sehubungan dengan kekerasan yang ia lihat terjadi pada ibunya, maupun secara tidak langsung. Bahkan, sebagian dari anak yang hidup di tengah keluarga seperti ini juga diperlakukan secara keras dan kasar karena kehadiran anak terkadang bukan meredam sikap suami tetapi malah sebaliknya.

Menurut hasil penelitian, menyaksikan kekerasan adalah pengalaman yang amat traumatis bagi anak-anak. Kekerasan dalam rumah tangga yang dialami anakanak membuat anak tersebut memiliki kecenderungan seperti gugup, gampang cemas ketika menghadapi masalah, sering ngompol, gelisah dan tidak tenang, jelek prestasinya di sekolah, mudah terserang penyait seperti sakit kepala, perut, dan asma, kejam kepada binatang, Ketika bermaian sering meniru bahasa yang kasar, berperilaku agresif dan kejam, suka minggat, dan suka melakukan pemukulan terhadap orang lain yang tidak ia sukai.

Kekerasan dalam rumah tangga yang ia lihat adalah sebagai pelajaran dan proses sosialisasi bagi dia sehingga tumbuh pemahaman dalam dirinya bahwa kekerasan dan penganiayaan adalah hal yang wajar dalam sebuah kehidupan berkeluarga. Pemahan seperti ini mengakibatkan anak berpendirian bahwa: 
a. Satu-satunya jalan menghadapi stres dari berbagai masalah adalah dengan melakukan kekerasan.

b. Tidak perlu menghormati perempuan.

c. Menggunakan kekerasan dalam menyelesaiakan berbagai persoalan adalah baik dan wajar.

d. Menggunakan paksaan fisik untuk mendapatkan sesuatu yang diinginkan adalah wajar dan baik-baik saja.

Di samping dampak secara langsung terhadap fisik dan psikologis sebagaimana disebutkan di atas, masih ada lagi akibat lain berupa hubungan negatif dengan lingkungan yang harus ditanggung anak seperti:

1. Harus pindah rumah dan sekolah jika ibunya harus pindah rumah karena menghindari kekerasan.

2. Tidak bisa berteman atau mempertahankan teman karena sikap ayah yang membuat anak terkucil.

3. Merasa disia-siakan oleh orang tua.

Kebanyakan anak yang tumbuh dalam rumah tangga yang penuh kekerasan akan tumbuh menjadi anak yang kejam. Penelitian membuktikan bahwa 50\%-80\% laki-laki yang memukuli istrinya atau anakanaknya, dulunya dibesarkan dalam rumah tangga yang bapaknya sering melakukan kekerasan terhadap istri dan anaknya. Mereka tumbuh dewasa dengan mental yang rusak dan hilangnya rasa iba serta anggapan bahwa melakukan kekerasan terhadap istri adalah bisa diterima. ${ }^{18}$

Rumah tangga merupakan unit terkecil dalam masyarakat sebagai wadah dan proses pergaulan hidup. ${ }^{19}$ Membina rumah tangga ada yang harmonis dan juga sebaliknya. Rumah tangga yang harmonis bisa terjadi karena beberapa faktor diantaranya kenyamanan, kecocokan, adanya tujuan dan kepercayaan. Sebaliknya, rumah tangga yang tidak harmonis terjadi karena beberapa faktor diantaranya tidak adanya kecocokan dan sering terjadi konflik. Konflik dalam kehidupan berumah tangga memang tidak bisa untuk dipungkiri. Ada pasangan yang bisa menyelesaikan konflik itu dengan baik seperti musyawarah, namun konflik yang berakhir dengan tidak baik akan berujung dengan tindak kekerasan.

Gejala-gejala istri yang mengalami kekerasan adalah merasa rendah diri, cemas, penuh rasa takut, sedih, putus asa, terlihat lebih tua dari usianya, sering merasa sakit kepala, mengalami kesulitan tidur, mengeluh nyeri yang tidak jelas penyebabnya, kesemutan, nyeri perut, dan bersikap agresif tanpa penyebab yang jelas. Jika anda membaca gejala-gejala di atas,

18 Mansour Fakih, Analisis Gender dan Transformasi Sosial, (Yogyakarta: Pustaka Pelajar, 2012), hlm. 17-18

19 Soerjono Soekanto, Sosiologi Keluarga Tentang Ikhwal Keluarga, Remaja dan Anak, (Jakarta: Rineka Cipta, 2009), hlm. 1 
tentu anda akan menyadari bahwa akibat kekerasan yang paling fatal adalah merusak kondisi psikologis yang waktu penyembuhannya tidak pernah dapat dipastikan. $^{20}$

Kekerasan terhadap perempuan bisa terjadi di mana saja, kapan saja dan oleh siapa saja. ${ }^{21}$ Bentuk kekerasan terhadap perempuan yang juga dapat dikategorikan sebagai kejahatan seksual atau gender based violence adalah kekerasan dalam keluarga atau yang dikenal dengan istilah domestic violence. ${ }^{22}$ Pengertian KDRT (kekerasan dalam rumah tangga) adalah setiap perbuatan terhadap seseorang terutama perempuan, yang berakibat timbulnya kesengsaraan atau penderitaan secara fisik, seksual, psikologis, dan atau penelantaran rumah tangga termasuk ancaman untuk melakukan perbuatan, pemaksaan, atau perampasan kemerdekaan secara melawan hukum dalam lingkup rumah tangga. ${ }^{23}$ Kekerasan dalam rumah tangga sendiri bisa terjadi karena berbagai hal dan alasan.

20 Komnas Perempuan (2002). Peta Kekerasan Pengalaman Perempuan Indonesia. Jakarta: Ameepro.

21 Fathul Djannah, Kekerasan Terhadap Istri, (Yogyakarta: LkiS, 2003), hlm. 2

22 Dadang S. Anshori, dkk, Membincangkan Feminisme: Refleksi Muslimah Atas Peran Sosial Kaum Wanita, (Bandung: Pustaka Hidayah, 1997), hlm. 79

${ }^{23}$ Undang-Undang Nomor 23 Tahun 2004 Tentang Penghapusan Kekerasan Dalam Rumah Tangga, Bab I Ketentuan Umum, Pasal 1 ayat 1
Gambaran mengenai tingkat pemahaman masyarakat Desa Cangkring, Kecamatan Jenggawah terhadap UndangUndang Nomor 23 Tahun 2004 tentang penghapusan kekerasan dalam rumah tangga adalah rendah, hal ini nampak ketika masyarakat diwawancara langsung oleh peneliti dan diminta untuk mengisi kuisioner. Mayoritas masyarakat yang diteliti oleh peneliti tidak tahu bahwa ada Undang-Undang khusus Nomor 23 Tahun 2004 yang mengatur tentang penghapusan kekerasan dalam rumah tangga, sehingga tingkat pemahaman mereka juga rendah tentang macam-macam kekerasan yang sudah diatur dalam Undang-Undang PKDRT tersebut.

Salah satu tokoh masyarakat sekaligus ketua RT, bernama Mistaha beserta istrinya, menjelaskan bahwa mereka berdua belum pernah tahu jika ada UndangUndang khusus yang mengatur tentang kekerasan dalam rumah tangga. Mereka juga tidak mengetahui bahwa kekerasan bukan hanya sekedar kekerasan fisik, namun juga ada kekerasan dari segi psikis. Mereka hanya tahu jika ada seorang suami yang memukul istrinya secara berlebihan artinya mengakibatkan luka parah pada si istri itu bisa dikatakan kekerasan dalam rumah tangga dan bisa dihukum pidana.

Hal yang sama juga disampaikan beberapa masyarakat yg lain yaitu Ibu Husnia, bapak Saiful, Ibu Tatik dan 
suaminya, Ibu Fatmawati dan suaminya, Ibu Nafil dan suaminya, dan beberapa warga yang lain. Rata- rata warga hanya mengetahui bahwa jika ada seorang suami yang memukul istrinya secara berlebihan artinya mengakibatkan luka parah pada si istri itu bisa dikatakan kekerasan dalam rumah tangga dan bisa dihukum. Mereka tidak tahu tentang Undang-Undang khusus yang mengatur tentang kekerasan dalam rumah tangga, mereka tidak tahu bahwa kekerasan itu banyak macamnya, antara lain kekerasan fisik, kekerasan psikologis, kekerasan seksual, kekerasan ekonomi dan kekerasan penelantaran rumah tangga.

\subsection{Dampak Dari Pemahaman Masyarakat Tentang Undang- Undang Nomor 23 Tahun 2004 Tentang Penghapusan Kekerasan Dalam Rumah Tangga Terhadap Terjadinya Kekerasan Dalam Rumah Tangga}

Kekerasan (Terhadap Perempuan) dalam Rumah Tangga secara ringkas, adalah setiap tindakan kekerasan verbal maupun fisik, pemaksaan atau ancaman pada nyawa yang dirasakan pada seorang perempuan, apakah masih anak-anak atau sudah dewasa, yang menyebabkan kerugian fisik atau psikologis, penghinaan atau perampasan kebebasan dan yang melanggengkan subordinasi perempuan. Adapun pengertian kekerasan dalam rumah tangga, sebagaimana tertuang dalam rumusan Pasal 1 Deklarasi Penghapusan Tindakan Kekerasan terhadap Perempuan dapat disarikan sebagai setiap tindakan berdasarkan jenis kelamin yang berakibat kesengsaraan atau penderitaan perempuan secara fisik, seksual, atau psikologis, termasuk ancaman tindakan tertentu, pemaksaan atau perampasan secara sewenang-wenang baik yang terjadi di depan umum atau dalam kehidupan pribadi (keluarga). ${ }^{24}$

Lebih tegas lagi dapat dikatakan bahwa kekerasan terhadap perempuan dalam rumah tangga terutama digunakan untuk mengontrol seksualitas perempuan dan peran reproduksi mereka. Hal ini sebagaimana biasa terjadi dalam hubungan seksual antara suami dan istri di mana suami adalah pihak yang membutuhkan dan harus dipenuhi kebutuhannya, dan hal ini tidak terjadi sebaliknya.

Lebih jauh lagi Maggi Humm menjelaskan bahwa beberapa hal di bawah ini dapat dikategorikan sebagai unsur atau indikasi kekerasan terhadap perempuan dalam rumah tangga yaitu: $:^{25}$

\footnotetext{
24 Rahman, Anita. (2006). Pemberdayaan PerempuanDikaitkan Dengan 12 Area of Concerns (Issue Beijing, 1995). Tidak diterbitkan, Universitas Indonesia, Jakarta, Indonesia.

${ }^{25}$ WHO. (2006). Menggunakan Hak Asasi Manusia Untuk Kesehatan Maternal dan Neunatal: Alat untuk Memantapkan Hukum, Kebijakan, dan Standar Pelayanan. Jakarta: Dep. Kes. RI.
} 
1. Setiap tindakan kekerasan baik secara verbal maupun fisik, baik berupa tindakan atau perbuatan, atau ancaman pada nyawa.

2. Tindakan tersebut diarahkan kepada korban karena ia perempuan. Di sini terlihat pengabaian dan sikap merendahkan perempuan sehingga pelaku menganggap wajar melakukan tindakan kekerasan terhadap perempuan.

3. Tindakan kekerasan itu dapat berbentuk hinaan, perampasan kebebasan, dll.

4. Tindakan kekerasan tersebut dapat merugikan fisik maupun psikologis perempuan.

5. Tindakan kekerasan tersebut terjadi dalam lingkungan keluarga atau rumah tangga.

Dalam konteks Indonesia, kondisi dari budaya yang timpang telah menyebabkan hukum, dan sistem hukum (materiil hukum, aparat hukum, budaya hukum) yang ada kurang responsif dalam melindungi kepentingan perempuan. KUHAP sangat minim membicarakan hak dan kewajiban istri sebagai korban, ia hanya diposisikan sebagai saksi pelapor atau saksi korban. Begitu pula yang tercantum dalam Undang-Undang Nomor 1 Tahun 1974 Tentang Perkawinan Pasal 31 ayat (3): "Suami adalah kepala rumah tangga dan istri adalah ibu rumah tangga. Meski demikian, KUHP juga memuat peluang istri untuk mendapat keadilan. Kekerasan dan penganiayaan terhadap istri dalam KUHP merupakan tindak pidana yang sanksinya lebih besar sepertiga dari tindak pidana penganiayaan biasa atau dilakukan oleh dan terhadap orang lain, sebagaimana diterangkan dalam Pasal 351 s.d.355 KUHP.

Pernyataan dalam KUHP tersebut dipertegas lagi dengan keluarnya UndangUndang Nomor 23 Tahun 2004 Tentang Kekerasan Dalam Rumah Tangga (KDRT) pada tanggal 22 September 2004 yang merupakan hasil kerja cukup panjang dari berbagai elemen bangsa, baik dari pemerintah, parlemen, dan tentu saja masyarakat luas yang dalam hal ini diwakili oleh lembaga-lembaga yang mempunyai perhatian serius terhadap penyelesaian kekerasan dalam rumah tangga dan pembangunan hukum yang adil bagi seluruh lapisan masyarakat.

Adapun definisi kekerasan dalam rumah tangga menurut Undang-Undang Nomor 23 Tahun 2004 yaitu: "Kekerasan dalam rumah tangga adalah setiap perbuatan terhadap seseorang terutama perempuan, yang berakibat timbulnya kesengsaraan atau penderitaan secara fisik, seksual, psikologis, dan penelantaran rumah tangga, termasuk ancaman untuk melakukan perbuatan, pemaksaan atau 
perampasan kemerdekaan secara melawan hukum dalam lingkup rumah tangga.

Data dari hasil Survei Kekerasan terhadap Perempuan dan Anak Tahun 2006 oleh BPS dan Kementerian Negara Pemberdayaan Perempuan, khususnya mengenai Tindak Kekerasan terhadap Perempuan menurut Pelaku, menunjukkan bahwa: sebanyak $51,1 \%$ (pelaku: suami); 11,7\% (pelaku: orang tua/mertua, anak/cucu, dan famili); 19,6\%(pelaku: tetangga); 2,5\%(pelaku: atasan/majikan); 2,9 (pelaku: rekan kerja); 0,2\% (pelaku: guru); dan 8,0\% (pelaku: lainnya).

Gejala-gejala istri yang mengalami kekerasan adalah merasa rendah diri, cemas, penuh rasa takut, sedih, putus asa, terlihat lebih tua dari usianya, sering merasa sakit kepala, mengalami kesulitan tidur, mengeluh nyeri yang tidak jelas penyebabnya, kesemutan, nyeri perut, dan bersikap agresif tanpa penyebab yang jelas. Jika anda membaca gejala-gejala di atas, tentu anda akan menyadari bahwa akibat kekerasan yang paling fatal adalah merusak kondisi psikologis yang waktu penyembuhannya tidak pernah dapat dipastikan. $^{26}$

Ratna Batara Munti menjelaskan bahwa kekerasan terhadap perempuan dalam rumah tangga dapat terjadi dalam

Komnas Perempuan (2002). Peta Kekerasan Pengalaman Perempuan Indonesia.Jakarta: Ameepro. berbagai bentuk sebagaimana diringkaskan di bawah ini yaitu $:^{27}$ Kekerasan fisik, Kekerasan psikologis, Kekerasan Seksual, Kekerasan ekonomi, Penelantaran rumah tangga.

Gabungan dari berbagai kekerasan sebagaimana disebutkan diatas baik fisik, psikologis, maupun ekonomis. Dari keterangan tentang berbagai macam bentuk kekerasan dalam rumah tangga tersebut dapat diketahui bahwa kekerasan tersebut adalah suatu tindakan yang out of control yang dapat menjadi kebiasaan jahat yang dapat merugikan pasangan.

Dampak dari rendahnya pemahaman masyarakat Desa Cangkring tentang Undang-Undang PKDRT dan juga rendahnya pemahaman tentang berbagai bentuk kekerasan dalam rumah tangga menyebabkan tingginya kejadian kekerasan dalam rumah tangga baik disadari atau tidak. Hal ini didasarkan pada hasil wawancara langsung antara peneliti dengan beberapa masyarakat Desa Cangkring dan juga didasarkan pada hasil pengisian kuisioner oleh masyarakat Desa Cangkring. Beberapa warga antara lain, Ibu nafil, Ibu suliha, Ibu Fatmawati, Ibu Tatik, Ibu Anisa, Ibu zainab, Ibu maimunah, Ibu Rohimah, mereka menjelaskan bahwa

\footnotetext{
Rahman, Anita. (2006). Pemberdayaan PerempuanDikaitkan Dengan 12 Area of Concerns (Issue Beijing, 1995). Tidak diterbitkan, Universitas Indonesia, Jakarta, Indonesia.
} 
ketika bertengkar dengan suaminya, mereka kadang-kadang mendapat ucapan kasar dari suaminya dan menyebabkan ibu-ibu tersebut tertekan secara psikis, bahkan menyebabkan ibu-ibu ini mengalami penurunan nafsu makan karena psikisnya tertekan setelah bertengkar dengan suami. Bahkan ada beberapa warga Cangkring yang statusnya sebagai istri mendapat kekerasan secara fisik ringan dari suaminya ketika bertengkar.

Beberapa suami istri yang telah peneliti wawancara dan peneliti minta untuk mengisi kuisioner mengatakan bahwa hanya mengetahui jika ada seorang suami yang memukul istrinya secara berlebihan artinya mengakibatkan luka parah pada si istri itu bisa dikatakan kekerasan dalam rumah tangga dan bisa dihukum. Mereka tidak tahu tentang Undang-Undang khusus yang mengatur tentang kekerasan dalam rumah tangga, mereka tidak tahu bahwa kekerasan itu banyak macamnya, antara lain kekerasan fisik, kekerasan psikologis, kekerasan seksual, kekerasan ekonomi dan kekerasan penelantaran rumah tangga.

\section{KESIMPULAN}

Berdasarkan pembahasan pada bab sebelumnya, maka dapat diambil kesimpulan sebagai berikut:

1. Tingkat pemahaman masyarakat Desa Cangkring, Kecamatan Jenggawah, terhadap Undang-Undang Nomor 23 Tahun 2004 Tentang Penghapusan Kekerasan Dalam Rumah Tangga adalah masih rendah. Mereka tidak tahu bahwa kekerasan itu banyak macamnya, antara lain kekerasan fisik, kekerasan psikologis, kekerasan seksual, kekerasan ekonomi dan kekerasan penelantaran rumah tangga. Bahkan sebahagian besar warga tidak tahu jika ada UndangUndang khusus yang mengatur tentang kekerasan dalam rumah tangga. Hal ini didasarkan pada hasil penelitian berupa kegiatan wawancara dan pengisian kuisioner yang dilakukan oleh peneliti kepada masyarakat Desa Cangkring.

2. Dampak dari rendahnya pemahaman masyarakat Desa Cangkring tentang Undang-Undang PKDRT dan juga rendahnya pemahaman tentang berbagai bentuk kekerasan dalam rumah tangga menyebabkan tingginya kejadian kekerasan dalam rumah tangga baik terjadi secara disadari atau tidak. Hal ini didasarkan pada hasil wawancara langsung antara peneliti dengan beberapa masyarakat Desa Cangkring 
dan juga didasarkan pada hasil pengisian kuisioner oleh masyarakat Desa Cangkring.

\section{DAFTAR PUSTAKA}

\section{Buku}

Aroma Elmina Martha, Proses Pembentukan Hukum Kekerasan Terhadap Perempuan di Indonesia dan Malaysia, 2013 (Yogyakarta: Aswaja Pressindo,)

Dadang S. Anshori, dkk, Membincangkan Feminisme: Refleksi Muslimah Atas Peran Sosial Kaum Wanita, 1997 (Bandung: Pustaka Hidayah,)

Fathul Djannah, Kekerasan Terhadap Istri, 2003 (Yogyakarta: LKiS,)

Khoiruddin Nasution, Pengantar Studi Islam, $2010 \quad$ (Yogyakarta: ACAdeMIA,)

Komnas Perempuan. Peta Kekerasan Pengalaman Perempuan Indonesia. (2002) Jakarta: Ameepro.

Mansour Fakih, Analisis Gender dan Transformasi Sosial, 2012 (Yogyakarta: Pustaka Pelajar,)

Moerti Hadiati Soeroso, Kekerasan Dalam Rumah Tangga: Dalam Perspektif Yuridis - Viktimologis, 2010 (Jakarta: Sinar Grafika) 
Dep. Kes. RI. Neunatal: Alat untuk Memantapkan Hukum, Kebijakan, dan Standar Pelayanan. Jakarta:

Rahman, Anita. (2006). Pemberdayaan PerempuanDikaitkan Dengan 12 Area of Concerns (Issue Beijing, 1995). Tidak diterbitkan, Universitas Indonesia, Jakarta, Indonesia.

Soerjono Soekanto, Sosiologi Keluarga Tentang Ikhwal Keluarga, Remaja dan Anak, 2009 (Jakarta: Rineka Cipta,)

Sciortino, Rosalia dan Ine Smyth. (1997). Harmoni: Pengingkaran Kekerasan Domestik di Jawa. Jurnal Perempuan, Edisi: 3, Mei-Juni.

\section{Peraturan Perundang-Undangan}

Undang-Undang Dasar (UUD) Republik Indonesia Tahun 1945

Kitab Undang-Undang Hukum Pidana (KUHP)

Undang-Undang Nomor 23 Tahun 2004 Tentang Penghapusan Kekerasan Dalam Rumah Tangga

\section{Internet}

https://aepnurulhidayat.wordpress.com/201 5/04/06/makalah-tugas-kekerasan-dalamrumah-tangga-aep-nurulhidayah_rkm126201/comment-page-1/ 


\section{BIODATA SINGKAT PENULIS}

Ahmad Yunus adalah dosen tetap pada Prodi Ilmu Hukum Universitas Ibrahimy Situbondo. Menyelesaikan pendidikan Sajana Hukum pada Fakultas Hukum Universitas Jember tahun 2015. Menyelesaikan pendidikan magister dengan konsentrasi hukum pidana pada program Magister Ilmu Hukum Fakultas Hukum Universitas Jember tahun 2018.

Supianto adalah Dosen tetap pada Fakultas Hukum Universitas Islam Jember. Menyelesaikan pendidikan sarjana pada Fakultas Hukum Universitas Islam Jember tahun 2007 dan Magister Hukum pada Program Magister Ilmu Hukum Fakultas Hukum Universitas Jember pada tahun 2012. 